\title{
Exploring L2 Learners' Views on Language Learning Through Social Networking Sites at a Public Sector University, Sindh, Pakistan
}

\author{
Qammar-un-nisa Jatoi \\ MS Scholar, \\ English Language Development Center, Mehran University, Jamshoro \\ Shumaila Aijaz Memon \\ Assistant Professor, \\ English Language Development Center, Mehran University Jamshoro \\ Syed Waqar Ali Shah \\ Lecturer, \\ English Language Development Center, Mehran University Jamshoro
}

\begin{abstract}
Despite the fact that language researchers propose the integration of language learning and technology, Pakistani universities seem to be struggling between traditional and digital methodologies. E-learning and CALL are the products of such efforts in modern pedagogical practices. Social Networking Sites (SNS) are one of the available resources that mediate E-learning or digital learning and teaching. This Study explores the views of L2 learners on language learning through social networking sites. The qualitative approach has been used in the present study to address the issue. The participants $(n=10)$ were recruited using purposive sampling. The researchers used interview as a data collection tool. Participants' responses were analyzed by using extensive content analysis. The study found that Social networking sites (SNS) are helpful in learning English language; however, the individual experiences and practices influence the learning process. The study further finds that the vague boundary system of social sites is a hurdle in its implementation in educational system or digital learning/teaching styles. The study recommends that e-learning can be integrated into classroom to promote learners' autonomy and to connect L2 learners with digital world to experience new ways of literacy and learning.
\end{abstract}

Keywords: Social Networking sites, SNS, Independent learners, Digital learning

DOI: $10.7176 /$ JLLL/70-05

Publication date:July $31^{\text {st }} 2020$

\section{Introduction: E-learning and Social sites in Pakistan}

We are living in a digitalized world where our learning is highly influenced by modern technology and gadgets. E-learning is meant to incorporate informative and communicative digital means with learning and teaching styles (Arkorful \& Abaidoo, 2014). It enables us to have access to the online resources for the learning. Social networking sites are one of the E-learning resources. It was created while looking at requirements of communication. These sites are easily accessible, and varying features provide smooth handy communication.

More than $90 \%$ of college students use social networking site in Pakistan (IJCSI combined study, 2012). Pakistan is the country where traditional ways of teaching and learning are engraved in educational atmospheres. It is difficult for practitioners to utilize social networking sites for the purpose language learning. Intentional use of such sites is avoided most of the time. Research areas are open to social sites (E-learning), but west seems to be more positive and encouraging toward social networking site than south/east Asian countries said to be third world countries (Richards, 2004). Effectiveness of this resource in language learning area is under question.

In order to know these sites effectiveness in language classroom, we need to find out the users experience as learners. We cannot assume the results without considering the students experience and knowledge on the subject. The individual experience of the users of social sites can give us insight of the ways of which we can use to advance the area of E-learning in Pakistan. This study focuses the individual experiences and insights of learners as users to determine the use of social sites for the sake of Language learning.

The Purpose of this study is to see what can be the use of social networking site (SNS) in learning English language in the perception of learners. For the purpose of language learning various means are utilized but social networking sites may give effective results as these sites are manmade substitute for social interactions. It can provide better understanding of language usage in real life situations. This study explores the behavior and perception that can answer to the problems related to adoption of social networking sites for educational purposes. Based on the aim, the following objectives were set:

- To explore the perceptions of L2 learners on application of social networking sites in English language 
learning approach.

- $\quad$ To find out the reasons that obstruct social networking sites application in language classrooms

The research aims to look for answers to the questions as; what are the perceptions of L2 learners on application of social networking sites as an English language learning approach? What are the reasons that obstruct social networking sites application in language classrooms?

One of the other solution to this problem can be to not to block the content but cultivating the understanding in students of being able to decide appropriate or inappropriate content accordance of time and place (Bugeja , 2006). We can explore possible ways for mediating technology with different aspects of infrastructure of centers, especially educational. We are required to connect L2 learners with digital world to experience new ways of literacy and learning. World is changing and technology is part of daily life. L2 learners are also part of this new digital world. It is important to give them similar experience when they are learning. Psychological satisfaction of writing something and achieved something in target language is a factor that provokes learning and social networking is a platform for such outcomes (Greenhow and Robelia, 2009). Language learning classes are emphasized to equip digital resources to create digital learning environment

\subsection{Significance in Pakistan}

This study reveals the attitudes and issues regarding SNS and its application in E-learning. The research outcomes invite more research and practical work in the area E-learning in Pakistani context. Extent of SNS use and to what level it should be used is also suggested by this study. Attempt of the study is to make learning more interesting and encouraging for non-native learners or students. The study is to explore available chances for independent learners by exploring the views of students who are engaged in learning and using foreign language that is English.

\subsection{Studies on Social Network sites}

To understand the Idea of SNS as second language learning strategy we will have to look over the two schools of thoughts. First is Vygotsky's (1978) theory of Zone of proximal development that stresses on the role played by human interactions on learning. Second is Feuerstein et al.'s (2003) emphases on the role of mediator (significant other) on transmission of knowledge/cultural. Both theories provide enough support to the transmission of language and cultural knowledge through social interactions and communication. Mediation comes in different forms on an online environment. Online settings are available as handmade forms of real world. People at homes, schools and offices come and face each other on different social networks as we can see through Harrison, Richard and Michael (2009) project on identity concern on online communities, 'mediation' was depending on online users themselves they build it through negotiations, their attitudes toward their identities and friendship determined it.

Knowledge is Constructible if learner or the subject goes under experience. Theory of constructivism was presented by Piaget (1970) that emphasis on discovery learning by the learners. Child during his development goes through different stages which are usually his/her experiences of determining facts and knowledge. Experiences determine the child's mental growth. The process of assimilation and accommodation makes possible for a child to add or omit the ideas in the form of schema (knowledge). The discovery of new idea by having experience actively transforms learner's intellectual level to higher level. The physical and social environment is seemed as essential constructs to help the child develop knowledge. By actively indulge in the act they can explore the nature of problem and solution. Lourenco (2016) in a critical review on Piaget's development stages in particular made a remark that these stages are clearly conceptual tools which do exist. We cannot overlook here the constructive approach to language learning and teaching rising from applied linguistics and educational psychology (Burden \& Williams, 2003).According to social constructivism, the effective learning is output of the collective efforts of people working together (McMahon ,1997). The innermost idea at this point is, use of SNS for learning language skills can influence not only learning process but also increases learners personal experience in terms of cultural values and beliefs (Richard \& Michael, 2009).

World is changing constantly, and within reshaping world students need more encouraging and engaging learning experiences, requiring teachers to come with the innovative methodologies using modern sources in classrooms that must promote the dynamic ,energetic, imSplicit yet full of new experiences learning (Thomas \& Brown, 2011). The review of Finardi (2012) on L2 teaching and learning of four hybrid approaches finds that in traditional classes if technology is integrated then it would be reflected as best choice with regards to teaching practices.

The latest writing model is proposed by Bazerman (2016) who sees writing as socio-cognitive model that represents the qualities of writing to link, to process meaning, to interact with the audience/reader and to develop "voice". According to the socio-cognitive model on writing, writing complete system that more than written script. This theory on processing writing is new and requires teachers to teach writing skill with new technologies. However, teachers' role in introducing new approaches in classroom set up is significantly important as their efforts and use of digital means can bring advancement in language teaching context, especially writing (William 
\& beam, 2018). The academic setting is ideal for teaching writing skills, because children learn to understand the nature of the composition of writing and strengthen their writing skills at such formal settings (Mackenzie \& Petriwskyj, 2017). In terms of finding the influence of school settings and setting outside schools Sefton-Green \& Erstad (2016) examined the lives of learning young minds to know young students learning places and identities, and finds schooling as crucial part, says:

"Paradoxically then, the more we looked into 'learning lives' outside of the school, the more we were struck by the overwhelming power of schooling in terms of how it frames knowledge as well as how it authorizes pedagogic relationships"

Users of these systems are able to learn languages through rich social and cultural interaction with other learners, including their peers and native speakers, in both asynchronous and synchronous modes of learning", (Harrison, Thomas, 2009, pg, 120).

Facebook and other social networking sits have the potential to ensure focused learning and promising outcomes in language learning (Tapscott, 1998; Glenn, 2000; Hay, 2000; Bosch, 2009). Bosch (ibid) calls new generation the Net genres that needs interactive environment and hand-on inquiry-based approaches to learning. The idea is to shift the learning styles from formal to informal. Greenhow and Roblia (2009) conducted a study on new approaches of learning styles in low cost. The- study investigated language learning outcomes on MYSPACE through survey and interviews from learners. Outcome of the study of Greenhow and Roblia (2009) was that:

"Their (Students) beliefs about network production, maintenance, and development and the social and technical possibilities of the environment influenced these practices. Students used MySpace to craft a multidimensional self-presentation amidst an unfolding and complex social context. To do so they enacted multiple roles as actors, authors, producers, fans, and critics."

\subsection{Purpose and objective of the study}

The Purpose of this study is to see what can be the use of social networking site (SNS) in learning English language in the perception of learners. For the purpose of language learning various means are utilized but social networking sites may give effective results as these sites are manmade substitute for social interactions. It can provide better understanding of language usage in real life situations. This study explores the behavior and perception that can answer to the problems related to adoption of social networking sites for educational purposes.

Based on the aim, the following objectives were set:

- $\quad$ To explore the perceptions of L2 learners on application of social networking sites in English language learning approach.

- $\quad$ To find out the reasons that obstruct social networking sites application in language classrooms

The research aims to look for answers to the questions ; what are the perceptions of L2 learners on application of social networking sites as an English language learning approach? What are the reasons that obstruct social networking sites application in language classrooms?

\section{Research Methodology}

This study was based on qualitative method. The present researchers wanted to explore the perceptions of students on social networking sites and factors hindering these sites to become part of education. 'Qualitative approach' is concerned with subjective assessment of attitudes, opinions and behavior. Research in such a situation is a function of researcher's insights and impressions." (Kothari: 2004: 5).

\subsection{Data collection tool}

Data was collected through interviews. Interview is helpful to investigate hypothesis or suggest new hypothesis; it works as explanatory device in order to determine variables and relationships among variables of the subject in research (Cohen, Lawrence, \& Keith, 2007). The researchers constructed questions based on the topic to be investigated and further responses were elicited during the interview. The interview type was semi-structured.

\subsection{Participants}

Interviews were taken from 10 students of Public Sector University. The participants were undergraduates of English department, chosen after purposive sampling. Purposive sampling results recruitment of heterogeneous group through snowballing method (Creswell, 2012).

\subsection{Data Analysis}

Content Analysis was used to codify interview data. It is secondary text that is conversion of interview into concrete material or visual material (Creswell, 2012).

\section{Findings \& Discussions}

The findings of the study are based on qualitative interview conducted from L2 students to investigate their 
perceptions on applications and usefulness of social networking sites in English language class. The interview was recorded and transcribed before codification of data into themes and subthemes. Initial phase of interview was based on questions and replies. The phase was intended to know about the participants that how much time they spend on social sites, and what were their reasons. One common social networking site shared by all eight participants is FACEBOOK to which Participants kept logging in for different purposes frequently. The participants use these sites "about 5-10 minutes a day" (P4) or every other day. As one of the participants suggests, "I check social media every day or every other day" (P3). One of the participant claimed, "Depends on how much time I have." (P1). Moreover, on contradiction out of all one was not willing active user "Not more than 20 minutes, I $m$ not a regular user" (P7).

Key reason of participants for using social sites is communication. For communication, they join such sites and get in touch with friends and family. More than family other people they mentioned were relatives, colleagues, and people who were not part of their account. Basic reason of using social sites is to meet people who are already part of your total social network that is why we call it "Social networking site" (Boyd \& Ellison 2007). Networking on social sites donot refers that users are always in search of new individuals.

Participants' responses for their secondary purposes varied according to their interest Secondary reasons of these participants are varying with nature of their interest. For updates of current issues, Checking friends post, fun, sharing the pictures \& information, passing time, chatting, searching, to know new trends, to get up to date news, Entertainment, to get knowledge or toknow new trends and information "it depends on the purpose I come to the website there are different purposes... like to get knowledge of particular thing, to know what my family and, friends are doing and to share my own thing" (P8).

Sequencing interview into first brief and then detailed questions gave rise to three major categories. Following three major themes emerged:

- Attitudes toward Social Sites

- $\quad$ SNS \& language learning

- $\quad$ SNS reliability

\subsection{SNS \& Attitudes of Students}

First category deals with the feelings, likes and dislikes of the participants about social sites. Most of the participants argued that the attitude played major role in using SNS except for two. One of the participants believed social networking gives you sense of rationality by enhancing your ideas:

"Yeah! Quite favorable. We share our ideas and get different ideas from people all over the world. It enhances our knowledge..."(P2)

Participant P3 was favoring it because it gave insight to what was happening in world, also because everyone's opinions matter on these sites:

"Yes, it is favoring in a way, like I stated, that one gets to know what's going on in the world around...I think social networking gives space to everyone to express their opinions because everyone matters. (P3)

Negative opinions were from the participants who felt social sites are playing less crucial role in their lives. They were spending less time on social sites. It made one of the participants angry on how mass is doing on such sites now with comparison to old times:

"Social networking sites seem to be doing more bad than good. There is, admittedly, more exposure to important issues now, than there's was before these social networks came into existence..." (P6)

She felt crowd feels more comfortable or easy placing their opinion regarding issues on these sites but not on faces "... When the reality is far from it. Everyone, it seems, is more comfortable being rude and terrible to others when it's not to their faces and behind computer screens." (P6)

By keeping this opinion in mind our other participant clarified this point in a bit different manner. She favored social sites and mentioned such activities as part of such sites:

"Social networking is a vast area, where people not only communicate with each other but also comment and state whatever they want to. Social networking also helps people to build social relations with one another and voice against any trend which is inappropriate in a society we live in. Yes, it is favoring in a way, like I stated, that one gets to know what's going on in the world around." she said "On whole, I think social networking gives space to everyone to express their opinions because everyone matters.” (P3)

One of the other participant also favored social sites according to him responsibility is upon the user that how he creates environment around him or her on social sites which can be constructive or destructive:

"See, for me every aspect has its moral as well immoral functions closely related to each other. It is for the user how (s)he is engaging himself or herself with the given beneficiary. Either that very person can use the same beneficiary in non-sense and harmful manner that could prove as an utter destruction to his/her life. ”(P5)

To conclude it, Social networking sites give the users quick insight of ongoing trends of the world. It provokes the sense of rationality of users. Everything has its moral and immoral functions. Social sites can be beneficial or harmful or both, Depending on the given situation, users decide how they will utilize it. It indicates experience 
vary user to user based on the situations they encountered.

\subsection{SNS \& language learning of Students}

Learning is possible on social sites because of users' involvement and features offered by these sites. BartlettBragg (2006) stated Mixture of people both readers and writers come across to each other and form different relations, they form their own social identity through adapted content, share sequences of materials and associate and connect to other people.To specify it, online social networking sites such as Facebook offer online sensed boundaries and environment for realistic or informal learning by making content available to users ( Northocote\&Kendle, 2001).When asked for the features of social networking sites that could be useful for the users, participants tried to count them. There were a large number of features suggested by the participant.

Says participant number five one can get ideas or learn from different forms of social sites. According to his experience, you cannot enclose ideas on one platform they are scattered on these different social sites, learning opportunities are available in different forms:

Some of the ideas one can get from social blogs that one cannot find in restrictive junction of talks like on official pages. Whereas, to further validate the theory to its visualized form one can try for You-tube or daily motion sites quite beneficial in many forms. It depends on the individual itself how she or he tracks the ideas." (P5)

It helps in learning new language structure said participant:

"Sometimes I learn new words to some extent SNSs are helpful, in developing language like vocabulary, idioms phrases."(P4)

Out of eight participants, two participants were extreme posters/active users that were more active than others were. Active participation in a sense they were more active at commenting on pages post and discussions as one of them was interested in topics like religion, social issues and human's emotions and psychology. She mentioned she has joined groups where she takes lively participation in order to improve her English language:

"I have joined so many English speaking group where learning takes place through different ways and I am improving my. "( $(\mathrm{P} 2)$

The other participant likes to comment in discussions and talk to various people on different aspects, it helps to her brainstorm in L2 and such discussions swell the emotions and feelings she feels and Says:

"I do participate in debates to learn about the things and it is a fun thing to do. It swells your emotions and feeling and brainstorm... My interest in participating is for entertainment and for learning by hearing different perspective" (p8)

Learning on these sites is fun shared one of the participant. He said there are many ways that group together to create whole scenario of new world on these sites: : "learning is fun on social websites because you have different ways to learn it such as, watching videos, meeting the native people, learn through their culture,... it gives the whole scenario of the different world, it has no barrier or rules to follow in the learning." (P9)

On a query whether they have felt their language improvement has to do something with social sites or is there something they leant on these sites regarding to language.

"For me, I think English language itself cannot be perceived to get from one source to learn. Yes, it is one of the great sources to fully involve learners to use and further polish the skills already acquired in early stages." (P10) Communication on these sites is primary factor which is required for language learning said a participant:

"It does improve intensively, I mean the best way to learn a language is to communicate with the people and SNS is the best resources for that" (PI)

Language learning is possible on these sites. These sites have various ways to indulge its users in different activities. These different functions of social networking sites can be utilized to learn language. Users can have many opportunities to learn language. These users can create their own world on these sites. Learn and avail the chances available. New language structures are exposed to learners on these sites. Discussions are open for the users on pages and groups. Dwelling with the counter arguments in discussions fires up emotions of users to brainstorm and use new vocabulary. For polishing skills in English language, available resources like social networking sites are great. One of the key factors is communication itself. Communication is making Language Learning Possible.

\subsection{SNS Reliability in L2 language learning}

In a response to the question 'Do they feel that social networking sites are useful or reliable for education? Most of them agreed. However, some of them agreed. Participants shared their concerns some participants showed concerns toward social networking sites. Felt one participant, time is new there should be new version of literacy she kept saying:

"This is a digital age and as such, it is also a very user friendly age. The technology is designed to accommodate beginners, I think" (P6)

Before ending the conversation other participate felt she favors such sites but she is more worried about extensive usage of younger generation that seemed problematic to her, she said uneasily:

"As I see it, the younger generation is smarter and more updated because they have a huge circle to socialize 
with and learn much. I'd not say that the younger generation has failed in other areas of life. "( $p 7)$

One of them said technology is designed to accommodate users and beginners:

“... Few people who are socially connected on the websites and actually disconnected in their real lives...” (P3)

It is difficult to practice on social sites. Classroom environment is enclosed in a system compared to social sites, said participant confusingly:

"Ideas is quite vague. one cannot perceive to get them enclose ..."(P5)

No age limitation for the users is one of the factors that were discussed by the participant:

P5: "these sites do not consider the age restriction. This in turn could prove problematic for its young user" ( $p 5)$ To summarize it, there is a possibility to utilize these sites in our classrooms as mean of language learning tool. Social networking can be utilized if whole system of social sites becomes easier to predict and handle. The vague boundaries of these sites are making it impossible. Users of different ages use these sites without any limitation. This is lead young generation toward excessive bridging with these sites.

\section{Conclusion}

Second language learning demands mixture of approaches. Our educational sectors require innovation in language courses. Language classes can be incorporated with technology to make learning exciting for the learners. In Pakistan digital learning and teaching approaches are still in phase of development. This study explored students' perceptions regarding social networking sites that can help learners learn language in similar virtual settings of real world. The present researchers wanted to find out reasons that were stopping the practitioners to implement Social networking sites in language classrooms. Three major findings rose out of the analysis of interview. First, Attitudes about social networking sites vary due to various experiences encounter on these sites. It can be harmful as well as beneficial for users. All depends on learners how he/she uses the source. Second, language learning is possible on these sites. Many features and settings are available that the users or practitioners can collaborate in language classes. Students' shared many features and experiences which were posing possibility for effective learning on these sites. Third and last major finding dealt with reasons that are making social networking become part of second language learning settings. Excessive use of the sites is problematic for the users. Users start bridging the real and virtual settings extremely. Virtual settings on social Networking sites lack atmosphere like classroom settings. These sites have vague boundaries that do not stop users to remain inside the definite walls of classrooms. Users cannot be restricted inside the walls; there are many factors that can distract them from learning.

\section{References}

Arkorful, V. and Abaidoo, N. (2014) The Role of e-Learning, the Advantages and Disadvantages of Its Adoption in Higher Education. International Journal of Education and Research, 2, 397-410.

Bazerman, Charles. (2018). Lifespan longitudinal studies of writing development: A heuristic for an impossible dream, 2ndHalf.

Bosch, T. E. (2009). Using online Social networking for teaching and learning: Facebook use at the University of Cape Town. South African Journal for communication .

Boyd dm, \& Ellison NB, ( 2007), 'Social networks: Definition, history, and scholarship', Journal of ComputerMediated Communication, vol. 13, no. 1, viewed 5 January 2009

Bugeja, M. (2006). Heads up: Facing the Facebook

Burden, R. \& Williams, M.(2003), 'A cognitive processing approach to motivation in foreign language learning', Journal of Teachers of English Union of Thrace and Macedonia, vol. 10, pp. 3-7.

Cohen, L. , Lawrence, M., \& Keith, M. (2007). Research Methods in Education (Sixth ed.).New york, US and Canada: Routledge.

Creswell, J. W. (2012). Educational Research; Planning Conducting and Evaluating Quantitative and Qualitative Research (4th ed.).

a. m., \& m. y. (2013-2015). Impact of Information and Communication Technologies. (a. ahmed, Ed.) sang-e-meel.

Barnes, K., Raymond, C. M., \& S., P. F. (2007). Teaching and Learning with the Net Generstion. Journal of Online Education.

Bartlett-Bragg, A. (2007). Reflection on Pedagogy : Reframing Practice to Foster Informal Learning with Social Software.

Bosch, T. E. (2009). Using online social networking for teaching and learning:. SOUTH AFRICAN JOURNAL FOR COMMUNICATION THEORY AND RESEARCH, 35 (2).

Bosch, T. E. (2009). Using online Social networking for teaching and learning: Facebook use at the University of Cape Town. South African Journal for communication .

C.R.kothari. (2004). Research Mthodology; methods and techniques. New Age International (p) limited, publishers.

Christine Greenhow ,Beth Robelia . (2009). Old communicationation, New Literacies: Social Network Sites as Social Learning Resouces. Journal of Computer-Mediated Communication.

Christine Greenhow,Bet h Robelia. (2009). Old Communication, New Literacies: Social Network Sites as Social 
Learning Resources. Journal of Computer-Mediated Communication,University of Minnesota, .

Cohen, L., Lawrence, M., \& Keith, M. (2007). Research Methods (Sixth ed.). Newyorks, US and Canada: Routledge.

Creswell, J. W. (2012). Educational Research; Planning Conducting and Evaluating Quantitative and Qualitative Research (4th ed.).

Danah m. boyd, Nicole B. Ellison. (2007). Social Networking Sites : Defination, history, and Scholarships. Journalomputer-mediated Communication.

Donmus, V. (2010). The use of social networks in educational computer-game based. Procedia Social and Behavioral Sciences, pp. 1497-1503.

Feuerstein, R., Feuerstein, R., Falik, L., \& Rand, Y. (2003). The Dynamic Assessment of Cognitive Modification: The Learning Prosperity assessment Device: Theory instruments and technique. Jerusalem, Israel: The ICEP Press.

H.Falik, R. F. (2002). The dynamc Assessment of Cognitive Modifiablity. Internaretional Centre for the Enhancement of Learning potential.

Kothari, C. (2004). Resenarch Methodology ; Methods and Techniques.

Lious Cohen, Lawrence Mionion \& Keith Morrison. (2007). Research Methods in Education (Sixth ed.).

Louis Cohen,Lawrence Manion and Keith Morrison. (2007). Research Methods in Education (sixth ed.). New york, united states and canada: $\mathrm{R}$ o u $\mathrm{t} \mathrm{l}$ e d g e.

Lourenco, O. M. (2016). Development Stages, Piagetian Stages in Particular: A Critical Review. New Ideas in Psychology, 123-137.

Memon*, G. R. (spring 2007). Education in Pakistan: The Key Issues, Problems and The. Journal of Management and Social Sciences, 3.

nknsdksjd. (2001). nwo ,lk. mmskkplpl.

Richard Harrison,Michael Thomas. (2009). Identity in online communities: social networking sites. International Journal of Emerging Technologies \& Society, 7, 109 - 124.

Richard, C. (2004). From old to new Learning: Global Imperatives, Exemplary Asian Dilemmas and ICT as a key to Cultural Education. Globalisation, Societies and Education, 2(3).

Richardn Harrison, Micheal thomas. (n.d.). Identity in Online Communicaties: Social Networking Sites and Language Learning. Interrnational Journal of Emerging Technologies \& Society .

Richards, C. (2004, November). From old to new learning: global imperatives, exemplary Asian dilemmas and ICT as a key to cultural education. Globalisation, Societies and Education, 2(3).

Shabnoor Siddiqui, Tajinder Sing. (2016). Social Media its Impact with Positive and Negative aspects. International Journal of Computer Applications Technology and Research.

Valentina Arkorful, Nelly Abaidoo. (2014, December). The role of e-learning, the advantages and disadvantages of its adoption in Higher Education. International Journal of Education and Research, 2.

Vygotsky, L. (1978). Mind in society: The development of Higher Psychological processes.

w. t., m. m., m. k., \& faseeullah. (2012, july). The Impact of Social Media and Social Networks on Education. IJCSI International Journal of Computer Science Issues, 9(4), 407- 411.

W.Creswell, J. (2012). Educational Research;Planning, Conducting, and Evaluating Quantitative and Qualitative Research. (K. Mason, Ed.) TexTech International.

Finardi, K. R. (2012). Technology and L2 learning: Hybridizing the curriculum. In M. S. Beck, R. Silveira, S. B. Funck, \& R. p. Xevier, III Congresso Internacional Abrapui, Language and Literature in the Age of Technology-Anais. Florianopolis: Universidade Federal de Santa.

Glenn, J. (2000). Teaching the Net-Generation. Business Education Forum 54(3): 6-14.

Hay, L. ( 2000). Educating the Net-Generation. The Social Administrator 57(54): 6-10

Kothari, C. (2004). Resenarch Methodology ; Methods and Techniques.

Lourenco, O. M. (2016). Development Stages, Piagetian Stages in Particular: A Critical Review. New Ideas in Psychology, 123-137.

Mackenzie, N. M., \& Petriwskyj, A. (2017). Understanding and supporting young writers: Opening the school gate. Australasian Journal of Early Childhood.

McMahon M 1997. 'Social constructivism and the World Wide Web - A paradigm for learning', Paper presented at the ASCILITE conference, Perth, Australia.

Piaget, J. (1970). Science of education and the psychology of the child. New York: Viking

a. m., \& m. y. (2013-2015). Impact of Information and Communication Technologies. (a. ahmed, Ed.) sang-e-meel.

Barnes, K., Raymond, C. M., \& S., P. F. (2007). Teaching and Learning with the Net Generstion. Journal of Online Education.

Bartlett-Bragg, A. (2007). Reflection on Pedagogy : Reframing Practice to Foster Informal Learning with Social Software.

Bosch, T. E. (2009). Using online social networking for teaching and learning:. SOUTH AFRICAN JOURNAL 
FOR COMMUNICATION THEORY AND RESEARCH, 35 (2).

Bosch, T. E. (2009). Using online Social networking for teaching and learning: Facebook use at the University of Cape Town. South African Journal for communication .

C.R.kothari. (2004). Research Mthodology; methods and techniques. New Age International (p) limited, publishers.

Christine Greenhow ,Beth Robelia . (2009). Old communicationation, New Literacies: Social Network Sites as Social Learning Resouces. Journal of Computer-Mediated Communication.

Christine Greenhow,Bet h Robelia. (2009). Old Communication, New Literacies: Social Network Sites as Social Learning Resources. Journal of Computer-Mediated Communication, University of Minnesota, .

Cohen, L., Lawrence, M., \& Keith, M. (2007). Research Methods (Sixth ed.). Newyorks, US and Canada: Routledge.

Creswell, J. W. (2012). Educational Research; Planning Conducting and Evaluating Quantitative and Qualitative Research (4th ed.).

Danah m. boyd, Nicole B. Ellison. (2007). Social Networking Sites : Defination, history, and Scholarships. Journalomputer-mediated Communication.

Donmus, V. (2010). The use of social networks in educational computer-game based. Procedia Social and Behavioral Sciences, pp. 1497-1503.

Feuerstein, R., Feuerstein, R., Falik, L., \& Rand, Y. (2003). The Dynamic Assessment of Cognitive Modification: The Learning Prosperity assessment Device: Theory instruments and technique. Jerusalem, Israel: The ICEP Press.

H.Falik, R. F. (2002). The dynamc Assessment of Cognitive Modifiablity. Internaretional Centre for the Enhancement of Learning potential.

Kothari, C. (2004). Resenarch Methodology ; Methods and Techniques.

Lious Cohen, Lawrence Mionion \& Keith Morrison. (2007). Research Methods in Education (Sixth ed.).

Louis Cohen,Lawrence Manion and Keith Morrison. (2007). Research Methods in Education (sixth ed.). New york, united states and canada: R o u $\mathrm{t} 1 \mathrm{e}$ d g e.

Lourenco, O. M. (2016). Development Stages, Piagetian Stages in Particular: A Critical Review. New Ideas in Psychology, 123-137.

Memon*, G. R. (spring 2007). Education in Pakistan: The Key Issues, Problems and The. Journal of Management and Social Sciences, 3.

nknsdksjd. (2001). nwo ,lk. mmskkplpl.

Richard Harrison,Michael Thomas. (2009). Identity in online communities: social networking sites. International Journal of Emerging Technologies \& Society, 7, 109 - 124.

Richard, C. (2004). From old to new Learning: Global Imperatives, Exemplary Asian Dilemmas and ICT as a key to Cultural Education. Globalisation, Societies and Education, 2(3).

Richardn Harrison , Micheal thomas. (n.d.). Identity in Online Communicaties: Social Networking Sites and Language Learning. Interrnational Journal of Emerging Technologies \& Society .

Richards, C. (2004, November). From old to new learning: global imperatives, exemplary Asian dilemmas and ICT as a key to cultural education. Globalisation, Societies and Education, 2(3).

Shabnoor Siddiqui, Tajinder Sing. (2016). Social Media its Impact with Positive and Negative aspects. International Journal of Computer Applications Technology and Research.

Valentina Arkorful, Nelly Abaidoo. (2014, December). The role of e-learning, the advantages and disadvantages of its adoption in Higher Education. International Journal of Education and Research, 2.

Vygotsky, L. (1978). Mind in society: The development of Higher Psychological processes.

w. t., m. m., m. k., \& faseeullah. (2012, july). The Impact of Social Media and Social Networks on Education. IJCSI International Journal of Computer Science Issues, 9(4), 407- 411.

W.Creswell, J. (2012). Educational Research;Planning, Conducting, and Evaluating Quantitative and Qualitative Research. (K. Mason, Ed.) TexTech International. 